\title{
Variation in Total Polyphenolic Contents, DNA Protective Potential and Antioxidant Capacity from Aqueous and Ethanol Extracts in Different Plant Parts of Hypericum perforatum L.
}

\author{
Nazim Sekeroglu ${ }^{*}$ Emrah Urlu², Muhittin Kulak², Sevgi Gezici³ ${ }^{3}$ Raman Dang ${ }^{4}$ \\ ${ }^{1}$ Vocational School, Medicinal \& Aromatic Plants Programme, University of Kilis 7 Aralık, 79000, Kilis, TURKEY. \\ ${ }^{2}$ Department of Biology, Faculty of Arts \& Sciences, University of Kilis 7 Aralık, 79000, Kilis, TURKEY. \\ ${ }^{3}$ Department of Biology, Faculty of Arts \& Sciences, University of Gaziantep, 27310, Gaziantep, TURKEY. \\ ${ }^{4}$ Department of Pharmacognosy \& Phytochemistry, Al-Ameen College of Pharmacy, University of Bangalore, 560 027, Karnataka, \\ INDIA.
}

\begin{abstract}
Background and Purpose: Hypericum perforatum belonging to the family Hypericaceae is a reputed medicinal plant including a wide ranges of important phytochemical components. Chlorogenic acid, rutin, hyperoside, quercitrin, quercetin, pseudohypericin, hypericin and hyperforin are of the major components. Crude extract and individual compounds of $H$. perforatum have been reported to exert antidepressant, antibiotic, and antitumoral activities. It is worthy to note that the quantity and efficacies of the crude extracts or individual compound are not constant, which are strongly influenced by different climatic conditions, harvesting times, harvested plant organs and post-harvest practices. Hence, numerous studies on $H$. perforatum collected from different parts of the World are carried out for their desired quality and biological efficacy. Methods: Wild collected plant materials were dried and preserved with a voucher specimen number and were extracted using maceration at room temperature for $24 \mathrm{~h}$ in dark. Subsequently, extracts were screened for their phenolic and flavonoid contents, plausible antioxidant activities using two methods namely DPPH radical scavenging and ferric-reducing antioxidant power (FRAP) assays and DNA protective activities. Results: The highlights of the study were are listed as 1) the highest total phenolic content in ethanol extracts of leaf, ii) the highest total flavonoid content in flower, iii) DPPH scavenging activity in leaf $(80.51 \%)$, flower $(63.42 \%)$ and stem $(48.20 \%)$, iv) highest ferric reduction capacity in ethanol extracts of stem were determined. Also, potent DNA protection activity was observed even at the lowest concentration value $(25 \mu \mathrm{g} / \mathrm{ml})$ of the extracts. Conclusion: The phenolic content and strong antioxidant activities of ethanol extracts of different parts of the plant are reported. All the extracts exhibited strong DNA protective activities in response to the $U V$ radiation in the presence of hydrogen peroxide.
\end{abstract}

Key words: Antioxidant, DNA protective activity, Flavonoid, Hypericum perforatum L., Phenolic.

\section{INTRODUCTION}

Wide range of curative properties made Hypericum species reported as medicinal plants all over the world throughout the human history. Because of its distinguished phytochemical composition, especially rich in naphthodianthrones (pseudohypericin, hypericin, hyperforine etc.) of which pharmaceutical efficiency for a dozen of illnesses scientifically approved, HP has a special importance in pharmaceutical market. ${ }^{1,2}$ Thus, scientific studies have recently been focused on this particular species. Wild collection and field cultivation of some cultivars are the main resources of HP in the market. Although field cultivation for standardized drug supply,
Submission Date: 01-12-2016; Revision Date: 03-01-2017; Accepted Date: 14-03-2017

DOI: $10.5530 / \mathrm{ijper.51.2s.43}$ Correspondence: Nazim Sekeroglu, Vocational School, Medicinal \& Aromatic Plants Programme, University of Kilis 7 Aralık, 79000, Kilis, TURKEY.

Phone: +90 5324015512 E mail: nsekeroglu@gmail. com

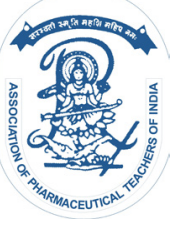

www.ijper.org 
wild collection (especially in Turkey) has continued now. Wild collected and dried raw plant materials in Turkey have totally been exported to Europe, processed on there and marketed. Thus, wild grown HP plants throughout the Turkey maintain their importance and scientific works related to these materials have scientifically important. ${ }^{1-3}$

Free radical and reactive oxygen species are highly unstable molecules that are either synthesized endogenously e.g. a product of energy metabolism as a part of oxidation chemical process or produced as a consequences of exogenous factors such as stress, cigarette smoking, imbalanced diet, alcohol, pollutants or sunlight. ${ }^{3}$ Subsequently, production or an overload of free radicals modify the structure of lipid, carbohydrate, protein and complex macromolecules and are subsequently linked to the certain diseases including cancer, diabetes, cardiovascular, age related and neurological disorders. ${ }^{4-9}$ The degradation or removal of the free radicals may not be completely controlled by endogenous enzymes such as superoxide dismutase, glutathione, but herbal products rich in phenolic contents are reported to possess important roles in the prevention of oxidation deterioration and decreasing the levels of free radicals and for this reason, many traditional plants have been screened for their phenolic content and free radical scavenging activities. ${ }^{10,11}$ Hydrogen peroxide, superoxide anion, hydroxyl and nitric oxide radical are free radicals, that producing during cellular oxidation naturally, are unstable and highly reactive molecules. ${ }^{12}$ Hydrogen peroxide $\left(\mathrm{H}_{2} \mathrm{O}_{2}\right)$ in the presence of UV, a known reactive oxygen species (ROS) generating system, is capable of producing molecules containing unpaired electrons named as free radicals that can damage biomolecules including proteins, lipids, carbohydrates, enzymes, RNA and DNA. When reactive oxygen species interact with DNA molecules, it affects the formation of DNA strand and causes single and double strand breaks in the DNA. ${ }^{13}$ This change of the DNA formation may result in development some disorders in genetically and also lead to develop diseases such as cancer, diabetes, aging, coronary artery, myocardial infection, rheumatoid arthritis, Alzheimer's disease and Parkinson's disease, etc. Adverse and toxic effects of the $\mathrm{H}_{2} \mathrm{O}_{2}$ can be prevented by antioxidants, which have important roles in scavenging all oxidant molecules by their hydroxyl group, thus providing protective effects on the DNA formation. ${ }^{14-16} \mathrm{HP}$ contains potential antioxidants that are effective against the DNA damage by directly reacting with the radicals, reducing peroxides and stimulating the antioxidative system. Therefore, in the current research, flower, stem and leaf of HP were extracted using water and ethanol, and aimed to investi- gate free radical scavenging activity by DPPH and ferric reducing assays, total phenolic and flavonoid contents of the extracts and thereafter DNA protective potentials in the presence of ultraviolet and hydrogen peroxide.

\section{MATERIALS AND METHODS Plant material}

All the above said parts of HP were collected in the flowering season from Kilis, Turkey in 2014 and after authentication; voucher specimens have submitted in the Biology Department at University of Kilis 7 Aralik, Turkey.

\section{Preparation of Extracts}

The air-dried and finely powdered stem, leaves and flower of HP (5 g) were stirred with $100 \mathrm{ml}$ of pure methanol for $30 \mathrm{~min}$, respectively. Extraction was carried out using maceration at room temperature for $24 \mathrm{~h}$ followed by filtration through Whatman No.4 filter paper. The extracts were then concentrated in vacuum at $40^{\circ} \mathrm{C}$ using a Rotary Evaporator. Then the extracts were preserved in sealed vials at $4^{\circ} \mathrm{C}$ until further analysis.

\section{Determination of Total Phenolic Content}

Total phenolic content was determined according to the Folin-Ciocalteu reagent method. ${ }^{17}$ The amount of total phenol was calculated as $\mathrm{mg} / \mathrm{g}$ (Gallic Acid Equivalents) from calibration curve of Gallic acid standard solution $\left(\mathrm{R}^{2}=0\right.$. 9993). An aliquot of each sample $(0.1 \mathrm{ml})$ was diluted to $1 \mathrm{ml}$ with distilled water. Briefly, $0.5 \mathrm{ml}$ of Folin-Ciocalteu reagent $(1: 1 \mathrm{v} / \mathrm{v})$ and $1.5 \mathrm{ml}$ of $20 \%$ $(\mathrm{w} / \mathrm{v})$ sodium carbonate was added to the diluted sample solution, and the mixture was then vortexed and allowed to stand for 2 hours at room temperature for color development. The volume was completed to $10 \mathrm{ml}$ with distilled water and their absorbance was measured at $765 \mathrm{~nm}$ (Evolution $201 \mathrm{UV}-$ Visible Spectrophotometer). The total phenolic content was expressed as $\mathrm{mg} / \mathrm{g}$ Gallic acid equivalents (GAE). All samples were analyzed in triplicate.

\section{Determination of Total Flavonoid Content}

The flavonoids content was determined by an aluminum chloride method using quercetine as a reference compound. ${ }^{18}$ This method based on the formation of a complex flavonoid-aluminum. The amount of total flavonoid was calculated from calibration curve of quercetine standard solution $\left(\mathrm{R}^{2}=0.9815\right) .1 \mathrm{ml}$ of extracts or standard quercetine solution $(500 \mu \mathrm{g} / \mathrm{ml})$ was added to $4 \mathrm{ml}$ distilled water and $0.3 \mathrm{ml}$ of $5 \% \mathrm{NaNO}_{2}$ was added. After 5 minutes, $0.3 \mathrm{ml}$ of $10 \% \mathrm{AlCl}_{3}$ was added. After $6 \mathrm{~min}, 2 \mathrm{~mL}$ of $1 \mathrm{~mol} \mathrm{L-} \mathrm{NaOH}$ was added and the 
final total volume was completed to $10 \mathrm{ml}$ with distilled water. The solution was thoroughly mixed. Afterwards the absorbance of the mixture was measured at $510 \mathrm{~nm}$ against prepared water as a blank. The total flavonoid content of extracts was expressed as $\mathrm{mg}$ quercetine equivalents $(\mathrm{QE}) / \mathrm{g}$ of dried leaf material.

\section{Scavenging Effect on 2, 2-diphenyl-1picrylhydrazyl (DPPH)}

The antioxidant activity of the extracts was evaluated by DPPH radical scavenging assay described by Blois. ${ }^{19}$ The reaction mixture including $1 \mathrm{ml}$ of DPPH solution $(0.1 \mathrm{mM}$ in methanol) and leaf extracts $(1 \mathrm{mg} / \mathrm{ml}-0.500$ $\mathrm{mg} / \mathrm{ml}-0.250 \mathrm{mg} / \mathrm{ml}-0.125 \mathrm{mg} / \mathrm{ml}$ ) adjusted to $3 \mathrm{ml}$ by adding methanol were left at room temperature in dark for $30 \mathrm{~min}$ and initial absorbance and absorbance after 30 min-incubation was measured at $517 \mathrm{~nm}$. The assays were carried out in triplicate. The DPPH radical scavenging percentage was calculated from the following equation;

$\%$ DPPH radical scavenging $=[($ control absorbance - extract absorbance)/control absorbance $] \times 100$

\section{Reducing Power Assay}

The reducing power was determined according to the method proposed byOyaizu. ${ }^{20}$ An aliquot of $1 \mathrm{ml}$ plant extracts $(1 \mathrm{mg} / \mathrm{ml}-0.500 \mathrm{mg} / \mathrm{ml}-0.250 \mathrm{mg} / \mathrm{ml}-0.125$ $\mathrm{mg} / \mathrm{ml}$ ) was mixed with $2,5 \mathrm{ml}$ of phosphate buffer $(0.2 \mathrm{M}, \mathrm{pH}=6.6)$ and $2,5 \mathrm{ml}$ of $\mathrm{K}_{3} \mathrm{Fe}(\mathrm{CN})_{6}(1 \%)$, shaken well and left for incubation at $50^{\circ} \mathrm{C}$ for $20 \mathrm{~min}$. After incubation, $2,5 \mathrm{ml}$ of TCA $(10 \%)$ was added in order to stop the reaction and the mixture was centrifuged at $1000 \mathrm{rpm}$ for $10 \mathrm{~min} .2,5 \mathrm{ml}$ of supernatant, $2,5 \mathrm{ml}$ of distilled water and $0,5 \mathrm{ml}$ of $\mathrm{FeCl}_{3}(1 \%)$ was mixed and incubated for $10 \mathrm{~min}$ and absorbance was read at $700 \mathrm{~nm}$ on spectrophotometer. The assays were carried out in triplicate.

\section{DNA Protective Potential}

The other aim of this study was to investigate DNA damage protection potentials of HP against to the DNA damage generated by hydrogen peroxide $\left(\mathrm{H}_{2} \mathrm{O}_{2}\right)$ and ultraviolet (UV)-known as reactive oxygen species (ROS) generating system. The DNA protective activity of the water and ethanol extracts from stem, leaves and flowers of $\mathrm{HP}$ was analyzed using pBR322 plasmid DNA (Vivantis) in the presence of $\mathrm{UV} / \mathrm{H}_{2} \mathrm{O}_{2}$ described previously $^{21,22}$ with some modifications. For analysis, different experimental groups were used, including control (untreated pBR322 plasmid DNA, treated with $\mathrm{H}_{2} \mathrm{O}_{2}$ and UV pBR322 plasmid DNA, treated with only $\mathrm{H}_{2} \mathrm{O}_{2}$ pBR322 plasmid DNA and treated with only UV pBR322 plasmid DNA) and treated groups with different concentration of extracts (ranging from $25 \mu \mathrm{g} / \mathrm{ml}$ to $200 \mu \mathrm{g} / \mathrm{ml}$ ) and $\mathrm{H}_{2} \mathrm{O}_{2}$ and UV. Briefly, the experiments were held a volume of $10 \mu \mathrm{l}$ in a micro centrifuge tube, firstly pBR322 super coiled plasmid DNA (200ng) was added to each tube, after that plant extracts were added (except the control samples), and then $\mathrm{H}_{2} \mathrm{O}_{2}$ was added to a final concentration of $2.5 \mathrm{mmol} / \mathrm{L}$ (except one of the control sample), finally all of the samples exposed to UV light for 5-8 min on a UV trans illuminator at 300 $\mathrm{nm}$ at room temperature. At the end of the reaction, loading buffer (10 mMTris- $\mathrm{HCl}, 0.15 \%$ orange G, $0.3 \%$ xylene cyanol, $60 \%$ glycerol, $60 \mathrm{mM}$ EDTA) was added in each reaction tube, analyzed in $1.5 \%$ agarose gel for electrophoresis at $100 \mathrm{~V}$ for approximately $1 \mathrm{~h}$, in Tris-borate-EDTA gel buffer (TBE-buffer) (45 Mm Tris-Borate, $1 \mathrm{mM}$ EDTA, $\mathrm{pH}$ 8.2), the gels were stained with ethidium bromide (EtBr) $(0.5 \mu \mathrm{g} / \mathrm{ml})$, and photographed under UV trans illuminator gel documentation system (VilberLourmat), finally DNA fragmentation patterns were separated by agarose gel electrophoresis.

\section{Statistical Analysis}

SPSS statistical program was used to determine statistical significance levels and the differences between individual averages were considered to be statistically important at $\mathrm{p}<0.05$ probability level.

\section{RESULTS AND DISCUSSION \\ Polyphenolic contents of HP}

A reagent that Folin-Ciocalteu was used to determine total polyphenol in plant extracts. Folin-Ciocalteu reagent consists of a yellow acidic solution containing complex polymeric ions formed from phosphomolybdic and phosphotungsticheteropoly acids. ${ }^{23}$ The total phenolic contents in the different extracts of the flower, stem and leaves of HP were determined, and expressed as milligrams of gallic acid equivalent (GAE) per gram of dry plant. Polarity of different solvents was significantly influenced the total phenolic content $(\mathrm{P}<0.05)$. The studies were performed with water extracts that are usually consumed as herbal tea, and ethanol extraction was also used for comparison. The amount of total polyphenolic content in three ethanol extracts ranged 146. 35 to $182.93 \mathrm{mg} \mathrm{GAE} / \mathrm{g}$ and 88.93 to $175.41 \mathrm{mg}$ GAE/g for water extracts, as shown in Table 1.

Flavonoids, which are most commonly found and widely distributed in plant polyphenol compounds, were in the range of 7.95 to $20.50 \mathrm{mg} Q \mathrm{QE} / \mathrm{g}$ and 12.59 to $14.84 \mathrm{mg} \mathrm{QE} / \mathrm{g}$ for ethanol and water extracts, respectively in this study. The highest value was determined in ethanol extracts of flowers and the lowest content was 
ascertained in ethanol extracts of stem. Extractability of phenolic varied depending on the used solvents and plant parts, but worthy of mention is that the biological activity does not always depend on the amount of the polyphenol contents rather but depend on possible interaction of the bioactive components in the extracts.

\section{Antioxidant activities of HP}

Extracts of stem, leaf and flower of HP were subjected to a screening for antioxidant activity by two complementary tests, namely the reduction of 2,2-diphenyl1picrylhydrazyl (DPPH) and ferric reducing. The results of antioxidant activity in different extracts and parts of the species compared with the ascorbic acid and gallic acid as positive controls. The DPPH scavenging activities of HP were summarized in Table 2.

DPPH assay was used as a rapid screening method for evaluation of antioxidant capacity. 2,2-diphenyl1 picrylhydrazyl, purple-colored stable free radical is reduced into the yellow colored diphenylpicryl hydrazine. ${ }^{24}$ In this context, different plant extracts obtained using ethanol and water solvents were subjected to the DPPH free radical scavenging assay for comparison of their possible antioxidant activities and the results are expressed as an inhibition percentage of free radicals.
The ability of the extracts for removal of DPPH was determined on the basis of their concentration, inhibition percentage and the highest inhibition percentage exhibits the highest effects of the extracts. Herein, four experimental doses $(0.125$ to $1 \mathrm{mg} / \mathrm{ml})$ of extracts were used and the scavenging effects were determined to be dose-dependent for each extract $\left(\mathrm{R}^{2}=0.99\right)$. Accordingly, ethanol extracts of leaf demonstrated the highest inhibition (84\%) and were followed by flower $(72.37 \%)$ and stem $(54.9 \%)$ whereas the inhibition percentages for water extracts of the samples were $60.33 \%$ (flower), $53.07 \%$ (leaf) and $33.47 \%$ (stem) (Table 2).

Electron donation capacity with respect to the reducing power of compounds were reported to be associated with the antioxidant activity of the compound. ${ }^{25}$ Ferric reducing capacity is measured by the reduction of $\mathrm{Fe}$ $[(\mathrm{CN}) 6]^{3+}$ to $\mathrm{Fe}[(\mathrm{CN}) 6]^{2+}$. In this context, increase in absorbance due to the formation of the complex is the indicator of the increased reduction capacity. ${ }^{26}$ Accordingly, similar to the DPPH assay results, ethanol extracts of the samples exhibited a highest ferric reduction capacity. The highest increased reduction capacity was determined in ethanol extracts of stem samples and the lowest activity was observed in water extracts of the stem samples (Table 3).

\begin{tabular}{|c|c|c|c|c|c|c|}
\hline \multicolumn{3}{|c|}{ Table 1: Polyphenolic contents of Hypericum perforatum L. } \\
\hline \multirow{2}{*}{ Solvents/ parts } & \multicolumn{3}{|c|}{ TPC (mg GAE/g DW) } & \multicolumn{3}{c|}{ TFC (mg QE /g DW) } \\
\cline { 2 - 7 } & Flower & Stem & Leaf & Flower & Stem & Leaf \\
\hline Ethanol extract & 146,35 d & 159,49 c & 182,93 a & 20,50 a & 7,95 f & 15,20 b \\
\hline Water extract & 175,41 b & $88,93 \mathbf{f}$ & 125,99 e & 14,68 d & 12,59 e & 14,84 c \\
\hline
\end{tabular}

Results are expressed as mean of three replicates. Data were analyzed by ANOVA and within each column different letters indicate statistically different values according to LSD-test at $\mathrm{P}<0.05 ; \mathrm{mg} \mathrm{GAE} / \mathrm{g} \mathrm{DW}$, milligram Gallic acid equivalent per gram dry extract; mg QE /g DW, milligram quercetine equivalent per gram dry extract; TPC: Total phenolic content; TFC: Total flavonoid content.

\begin{tabular}{|c|c|c|c|c|c|c|c|c|}
\hline & \multicolumn{3}{|c|}{ Ethanol Extracts } & \multicolumn{3}{|c|}{ Water Extracts } & \multicolumn{2}{|c|}{ Standards } \\
\hline & Flower & Stem & Leaf & Flower & Stem & Leaf & GA & AA \\
\hline $1 \mathrm{mg} / \mathrm{ml}$ & $72,37 \mathbf{b}$ & 54,90 cd & 84,00 a & 60,33 c & 33,47 e & $53,07 \mathrm{~d}$ & 95,88 & 96,93 \\
\hline $0,5 \mathrm{mg} / \mathrm{ml}$ & $40,00 \mathrm{~b}$ & $29,53 \mathrm{c}$ & 50,37 a & $32,70 \mathrm{c}$ & $17,97 \mathbf{d}$ & $28,23 \mathrm{c}$ & 95,67 & 66,04 \\
\hline $0,25 \mathrm{mg} / \mathrm{ml}$ & 24,00 b & 18,17 c & $27,50 \mathbf{a}$ & $18,80 \mathrm{c}$ & $11,17 \mathbf{e}$ & $16,30 \mathrm{~d}$ & 84,10 & 32,74 \\
\hline $0,125 \mathrm{mg} / \mathrm{ml}$ & $11,13 \mathbf{b}$ & $10,93 \mathbf{b}$ & $14,60 \mathbf{a}$ & $11,10 \mathbf{b}$ & $6,60 \mathrm{~d}$ & $9,40 \mathrm{c}$ & 47,76 & 13,31 \\
\hline
\end{tabular}

Data are expressed as means of three replicates. The mean is significant at the 0.05 level and the results are expressed as inhibition percentage (\%). Data were analyzed by ANOVA and within each column different letters indicate statistically different values according to LSD-test at P<0.05; GA: Gallic acid; AA: Ascorbic acid; Notes-2: Standard antioxidant compounds, GA and AA, were excluded from statistical analysis. Mean of three replicates were presented in the Table 2. 


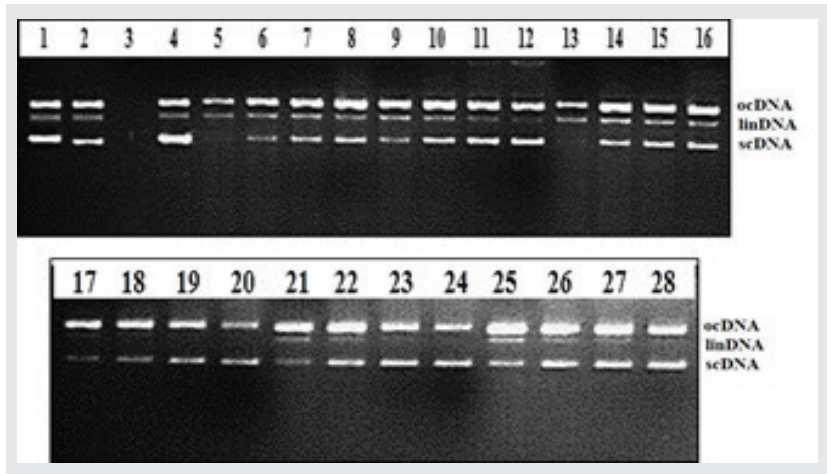

Figure 1: DNA protective activity of Hypericum perforatum L. extracts

Control Samples: Line 1, DNA + UV; Line 2, DNA; Line 3, DNA $+\mathrm{H}_{2} \mathrm{O}_{2}+$ UV; Line 4, DNA $+\mathrm{H}_{2} \mathrm{O}_{2}$. Line 5, DNA $+\mathrm{UV}+\mathrm{H}_{2} \mathrm{O}_{2}+$ the water extracts from leaves of $H$. perforatum at $25 \mu \mathrm{g} / \mathrm{ml}$ concentration; Line 6, DNA + UV $+\mathrm{H}_{2} \mathrm{O}_{2}$ + the water extracts from leaves of $\mathrm{H}$. perforatum at $50 \mu \mathrm{g} / \mathrm{ml}$ concentration; Line 7, DNA $+\mathrm{UV}+\mathrm{H}_{2} \mathrm{O}_{2}+$ the water extracts from leaves of $H$. perforatum at $100 \mu \mathrm{g} / \mathrm{ml}$ concentration; Line 8 , DNA + UV $+\mathrm{H}_{2} \mathrm{O}_{2}+$ the water extracts from leaves of $H$. perforatum at $200 \mu \mathrm{g} / \mathrm{ml}$ concentration; Line 9, DNA + UV $+\mathrm{H}_{2} \mathrm{O}_{2}+$ the water extracts from flowers of $H$. perforatum at $25 \mu \mathrm{g} / \mathrm{ml}$ concentration; Line 10, DNA + UV $+\mathrm{H}_{2} \mathrm{O}_{2}+$ the water extracts from flowers of $\mathrm{H}$. perforatum at $50 \mu \mathrm{g} / \mathrm{ml}$ concentration; Line $11, \mathrm{DNA}+\mathrm{UV}+\mathrm{H}_{2} \mathrm{O}_{2}+$ the water extracts from flowers of $\mathrm{H}$. perforatum at $100 \mu \mathrm{g} / \mathrm{ml}$ concentration; Line 12 , $\mathrm{DNA}+\mathrm{UV}+\mathrm{H}_{2} \mathrm{O}_{2}+$ the water extracts from flowers of $\mathrm{H}$. perforatum at 200 $\mu \mathrm{g} / \mathrm{ml}$ concentration; Line 13, DNA + UV $+\mathrm{H}_{2} \mathrm{O}_{2}+$ the water extracts from stem of $H$. perforatum at $25 \mu \mathrm{g} / \mathrm{ml}$ concentration; Line 14, DNA + UV $+\mathrm{H}_{2} \mathrm{O}_{2}$ + the water extracts from stem of $H$. perforatum at $50 \mu \mathrm{g} / \mathrm{ml}$ concentration; Line 15, DNA + UV $+\mathrm{H}_{2} \mathrm{O}_{2}+$ the water extracts from stem of $\mathrm{H}$. perforatum at $100 \mu \mathrm{g} / \mathrm{ml}$ concentration; Line $16, \mathrm{DNA}+\mathrm{UV}+\mathrm{H}_{2} \mathrm{O}_{2}+$ the water extracts from stem of $H$. perforatum at $200 \mu \mathrm{g} / \mathrm{ml}$ concentration; Line 17, DNA + $\mathrm{UV}+\mathrm{H}_{2} \mathrm{O}_{2}+$ the ethanol extracts from leaves of $H$. perforatum at $25 \mu \mathrm{g} / \mathrm{ml}$ concentration; Line 18, DNA + UV $+\mathrm{H}_{2} \mathrm{O}_{2}$ + the ethanol extracts from leaves of $H$. perforatum at $50 \mu \mathrm{g} / \mathrm{ml}$ concentration; Line $19, \mathrm{DNA}+\mathrm{UV}+\mathrm{H}_{2} \mathrm{O}_{2}+$ the ethanol extracts from leaves of $H$. perforatum at $100 \mu \mathrm{g} / \mathrm{ml}$ concentration; Line 20, DNA $+\mathrm{UV}+\mathrm{H}_{2} \mathrm{O}_{2}+$ the ethanol extracts from leaves of $H$. perforatum at $200 \mu \mathrm{g} / \mathrm{ml}$ concentration; Line $21, \mathrm{DNA}+\mathrm{UV}+\mathrm{H}_{2} \mathrm{O}_{2}+$ the ethanol extracts from flowers of $H$. perforatum at $25 \mu \mathrm{g} / \mathrm{ml}$ concentration; Line 22, $\mathrm{DNA}+\mathrm{UV}+\mathrm{H}_{2} \mathrm{O}_{2}+$ the ethanol extracts from flowers of $H$. perforatum at $50 \mu \mathrm{g} / \mathrm{ml}$ concentration; Line 23, DNA + UV $+\mathrm{H}_{2} \mathrm{O}_{2}+$ the ethanol extracts from flowers of $H$. perforatum at $100 \mu \mathrm{g} / \mathrm{ml}$ concentration; Line 24, DNA + $\mathrm{UV}+\mathrm{H}_{2} \mathrm{O}_{2}+$ the ethanol extracts from flowers of $H$. perforatum at $200 \mu \mathrm{g} / \mathrm{ml}$ concentration; Line 25, DNA + UV $+\mathrm{H}_{2} \mathrm{O}_{2}+$ the ethanol extracts from stem of $H$. perforatum at $25 \mu \mathrm{g} / \mathrm{ml}$ concentration; Line $26, \mathrm{DNA}+\mathrm{UV}+\mathrm{H}_{2} \mathrm{O}_{2}+$ the ethanol extracts from stem of $H$. perforatum at $50 \mu \mathrm{g} / \mathrm{ml}$ concentration; Line 27, DNA $+\mathrm{UV}+\mathrm{H}_{2} \mathrm{O}_{2}+$ the ethanol extracts from stem of $H$. perforatum at $100 \mu \mathrm{g} / \mathrm{ml}$ concentration; Line 28 , DNA $+\mathrm{UV}+\mathrm{H}_{2} \mathrm{O}_{2}+$ the ethanol extracts from stem of $H$. perforatum at $200 \mu \mathrm{g} / \mathrm{ml}$ concentration.

\begin{tabular}{|c|c|c|c|c|c|c|}
\hline & \multicolumn{3}{|c|}{ Ethanol Extracts } & \multicolumn{3}{|c|}{ Water Extracts } \\
\hline & Flower & Stem & Leaf & Flower & Stem & Leaf \\
\hline $1 \mathrm{mg} / \mathrm{ml}$ & $3,25 b$ & 3,27 a & $3,20 \mathrm{c}$ & $1,21 d$ & $0,59 \mathrm{f}$ & $1,01 \mathrm{e}$ \\
\hline $0,5 \mathrm{mg} / \mathrm{ml}$ & $3,18 \mathrm{a}$ & $3,14 b$ & $3,18 \mathrm{a}$ & $0,71 \mathrm{c}$ & $0,31 \mathrm{e}$ & $0,52 d$ \\
\hline $0,25 \mathrm{mg} / \mathrm{ml}$ & $2,86 a$ & $2,38 \mathrm{c}$ & $2,75 b$ & $0,40 \mathrm{~d}$ & $0,16 \mathrm{f}$ & $0,28 \mathrm{e}$ \\
\hline $0,125 \mathrm{mg} / \mathrm{ml}$ & $2,01 \mathrm{a}$ & $1,51 \mathrm{c}$ & $1,92 \mathrm{~b}$ & $0,20 d$ & $0,09 \mathrm{f}$ & $0,14 d$ \\
\hline
\end{tabular}

Results are expressed as mean of three replicates. Data were analyzed by ANOVA and within each column different letters indicate statistically different values according to LSD-test at $\mathrm{P}<0.05$.

\section{DNA protective activity of HP extracts}

DNA protection effect of HP extracts was investigated with plasmid DNA derived from $\mathrm{pBR} 322$ in the presence of ultraviolet and hydrogen peroxide. pBR322 plasmid DNA, isolated from Escherichia coli, has 4361 base pairs (bp) and on agarose gel electrophoresis shows two bands including scDNA (supercoiled circular DNA) and ocDNA (open circular DNA). scDNA is the native form of DNA derived from pBR322 and moves faster than ocDNA on gels. When DNA is exposed to UV light, in the presence of $\mathrm{H}_{2} \mathrm{O}_{2}$, this situation is leading to produce free hydroxyl radicals, and change native formation of DNA (scDNA), produced ocDNA and linear DNA (linDNA). ${ }^{22-27}$ The addition of the water and ethanol extracts of $\mathrm{HP}$ at $25 \mu \mathrm{g} / \mathrm{ml}-200 \mu \mathrm{g} / \mathrm{ml}$ concentration to the reaction mixture prevent to change the formation of linDNA, and help to protect the native formation of DNA (Figure.1).

Figure 1 shows the electrophoretic band pattern of pBR322 plasmid DNA after exposed to $\mathrm{UV} / \mathrm{H}_{2} \mathrm{O}_{2}$ in the absence and presence of the extracts of $\mathrm{HP}$ in a dose dependent manner (concentration of the extracts ranging from $25 \mu \mathrm{g} / \mathrm{ml}$ to $200 \mu \mathrm{g} / \mathrm{ml}$ ): first four lines are control samples, UV irritation of DNA in the absence of $\mathrm{H}_{2} \mathrm{O}_{2}$ (line 1), absence of $\mathrm{UV}$ and $\mathrm{H}_{2} \mathrm{O}_{2}$ (line 2), presence of UV and $\mathrm{H}_{2} \mathrm{O}_{2}$ (line 3), and presence of $\mathrm{H}_{2} \mathrm{O}_{2}$, without UV irritation of DNA (line 4), and the other lines are treated lines with the water and ethanol extracts from stem, leaves and flowers of HP.: lines 5 to 8 are the water extracts from leaves of HP, lines 9 to 12 are the water extracts from flowers of HP, lines 13 to 16 are the water extracts from the stem of $\mathrm{HP}$ at $25 \mu \mathrm{g} / \mathrm{ml}$ to $200 \mu \mathrm{g} / \mathrm{ml}$ concentration, lines 17 to 20 are the ethanol extracts from leaves of HP, lines 21 to 24 are the ethanol extracts from flowers of HP, lines 25 to 28 are the ethanol extracts from the stem of $\mathrm{HP}$ at $25 \mu \mathrm{g} / \mathrm{ml}$ to $200 \mu \mathrm{g} / \mathrm{ml}$ concentration. It was clearly demonstrated that all of the extracts from HP are able to provide DNA protection potentials against to UV radiation in the presence of hydrogen peroxide.

\section{CONCLUSION}

In conclusion, this study clearly evaluated that all of the extracts from different parts of HP are able to provide DNA protection potentials against to UV radiation in the presence of hydrogen peroxide. In addition, this plant has high total polyphenolic contents and strong antioxidant capacity was demonstrated in this research. Experimental evidence of the present study would help to understand that this plant has potential health benefits 
as a natural antioxidant. Moreover, the extracts and/or compounds obtained from different parts of HP might be used as natural anticancer agents, as well as antiaging products in daily life for the future with validation by further studies.

\section{ACKNOWLEDGEMENT}

The authors would like to thank to Kilis 7 Aralı University, Cenral Laboratory for their technical support.

\section{CONFLICT OF INTEREST}

Authors declare that they have no conflict of interest.

\section{ABBREVIATION USED}

AA: Ascorbic acid; DNA: Deoksiribo nükleic acid; DPPH: 2,2-diphenyl-1picrylhydrazyl; EtBr: Ethidium bromide; FRAP: ferric-reducing antioxidant power; GA: Gallic acid; GAE: Gallic acid equivalent; $\mathrm{H}_{2} \mathrm{O}_{2}$ : Hydrogen peroxide; HP: Hypericum perforatum; linDNA: lineer DNA; ocDNA: Open circular DNA; QE: Quercetine equivalents; RNA: Ribo nucleic acid; ROS: Reactive oxygen species; scDNA: supercoiled circular DNA; TFC: Total flavonoid content; TPC: Total phenolic content; UV: Ultraviolet.

\section{REFERENCES}

1. Upton N, Blackburn TP, Campbell CA, Cooper D, Evans ML, Herdon HJ, King PD, Ray AM, Stean TO, Chan WN, Evans JM, Thompson M.Profile of SB-204269, a mechanistically novel anticonvulsant drug, in rat models of focal and generalized epileptic seizures. British Journalof Pharmacology 1997;121(8):1679-86. https://doi.org/10.1038/sj.bjp.0701330; PMid:9283703 PMCid:PMC1564882.

2. Van Wyk BE, Wink M. Medicinal plants of the world: an illustrated scientific guide to important medicinal plants and their uses. Timber Press 2004.

3. Kumpulainen JT, Salonen JT. Natural antioxidants and anticarcinogens in nutrition, health and disease. (No.240).Elsevier 1999;178-87. https://doi. org/10.1533/9781845698409.

4. Halliwell B, Gutteridge JMC. Free radicals in biology and medicine. Oxford University Press, USA. 2015. https://doi.org/10.1093/ acprof:oso/9780198717478.001.0001.

5. Burhans WC, Weinberger M. DNA replication stress, genome instability and aging. Nucleic Acids Research. 2007;35(22):7545-56. https://doi. org/10.1093/nar/gkm1059; PMid:18055498PMCid:PMC2190710.

6. İshii $\mathrm{N}$. Role of oxidative stress from mitochondria on aging and cancer. Cornea 2007; 26:3-9. https://doi.org/10.1097/ICO.0b013e31812f6745; PMid:17881913.

7. Polidori MC, Griffiths HR, Mariani E, \&Mecocci P.Hallmarks of protein oxidative damage in neurodegenerative diseases: focus on Alzheimer's disease. Amino Acids 2007;32(4):553-9. https://doi.org/10.1007/s00726-0060431-x; PMid:17273806

8. Chakraborty A, Ferk F, Simic T, Brantner A, Dusinska M, Kundi M,Hoelzi C, Nersesyan A, \&Knasmüller S. DNA-protective of sumach (Rhuscoriaria L.), a common spice: results of human and animal studies. Mutation Research/ Fundamental and Molecular Mechanisms of Mutagenesis 2009;661(1):10-7. https://doi.org/10.1016/j.mrfmmm.2008.10.009; PMid:19022266.

9. Orhan IE, Atasu E, Senol FS, Ozturk N, Demirci B, Das K, \&Sekeroglu N. (2013) Comparative studies on Turkish and Indian Centellaasiatica (L.) Urban (gotu kola) samples for their enzyme inhibitory and antioxidant effects and phytochemical characterization. Industrial Crops and Products 2013;47:31622. https://doi.org/10.1016/j.indcrop.2013.03.022.

10. Adewusi EA, Steenkamp V. In vitro screening for acetylcholinesterase inhibition and antioxidant activity of medicinal plants from southern Africa. Asian Pacific Journal of Tropical Medicine 2011;4(10):829-35. https://doi. org/10.1016/S1995-7645(11)60203-4.

11. Karahan F, Kulak M, Urlu E, Gozuacik HG, Boyumez T, Sekeroglu N, Doganturk IH. (2015) Total phenolic content, ferric reducing and DPPH scavenging activity of Arum dioscoridis. Natural Product Research. 2015;29(17):1678-83. https://doi.org/10.1080/14786419.2014.991320; PMid:25520041.

12. Marnett LJ. Lipid peroxidation—DNA damage by malondialdehyde. Mutation Research/Fundamental and Molecular Mechanisms of Mutagenesis 1999;424(1):83-95. https://doi.org/10.1016/S0027-5107(99)00010-X.

13. Singh P, Vishwakarma SP, \&Singh RL. Antioxidant, oxidative DNA damage protective and antimicrobial activities of the plant Trigonellafoenum-graecum. Journal of the Science of Food and Agriculture 2014;94(12):2497-504.https:// doi.org/10.1002/jsfa.6585 PMid:24464686.

14. Pratico D. Evidence of oxidative stress in Alzheimer's disease brain and antioxidant therapy. Annals of the New York Academy of Sciences 2008;1147(1):70-8. https://doi.org/10.1196/annals.1427.010; PMid:19076432.

15. Elahi MM, Kong YX, \&Matata BM.Oxidative stress as a mediator of cardiovascular disease. Oxidative Medicine and Cellular Longevity 2009;2(5):259-69. https://doi.org/10.4161/oxim.2.5.9441; PMid:20716913 PMCid:PMC2835914.

16. Waris G, Ahsan H. Reactive oxygen species: role in the development of cancer and various chronic conditions. Journal of Carcinogenesis 2006;5(1):14. https://doi.org/10.1186/1477-3163-5-14; PMid:16689993 PMCid:PMC1479806.

17. Singleton VL, Orthofer R, Lamuela-Raventos RM. Analysis of total phenols and other oxidation substrates and antioxidants by means of Folin-Ciocalteu reagent. Methods in Enzymology 1999;299:152-78. https://doi.org/10.1016/ S0076-6879(99)99017-1.

18. Kumaran A. Antioxidant and free radical scavenging activity of an aqueous extract of Coleus aromaticus. Food chemistry 2006;97(1):109-14. https://doi. org/10.1016/j.foodchem.2005.03.032.

19. Blois MS. Antioxidant determinations by the use of a stable free radical, Nature 1958;26:1199-200. https://doi.org/10.1038/1811199a0.

20. Oyaizu M. Studies on product of browning reaction prepared from glucose amine. Japanese Journal of Nutrition 1986;44:307-15. https://doi. org/10.5264/eiyogakuzashi.44.307.

21. Attaguile G, Russo A, Campisi F, Savoca F, Acquaviva R, Ragusa N, Vanella A. Antioxidant activity and protective effect on DNA cleavage of extracts from Cistusincanus L. and Cistusmonspeliensis L. Cell Biology and Toxicology 2000;16(2):83-90. https://doi.org/10.1023/A:1007633824948; PMid:10917563.

22. Singh NP, Tice R., Stephens RE, Scheneider EL. A microgel electrophoresis technique for the direct quantitation of DNA damage and repair in individual fibroblasts cultured on microscope slides. Mutation Research/Environmental Mutagenesis and Related Subjects 1991;252(3):289-96. https://doi. org/10.1016/0165-1161(91)90008-V.

23. Singleton VL, Rossi JA. Colorimetry of total phenolics with phosphomolybdic - phosphotungstic acid reagents. American Journal of Enology and Viticulture 1965;16(3):144-58.

24. Conforti F, Statti GA, Tundis R, Menichini F, Houghton P. (2002) Antioxidant activity of methanolic extract of HypericumtriquetrifoliumTurra aerial part. Fitoterapia 2002;73(6):479-83. https://doi.org/10.1016/S0367326X(02)00162-4.

25. Arabshahi-Delouee S, Urooj A. Antioxidant properties of various solvent extracts of mulberry (Morusindica L.) leaves. Food Chemistry 2007;102(4):1233-40. https://doi.org/10.1016/j.foodchem.2006.07.013.

26. Koksal E, Gulcin I. Purification and characterization of peroxidase from cauliflower (Brassica oleracea L. var. botrytis) buds. Protein and Peptide Letters 2008;15(4):320-6. https://doi.org/10.2174/092986608784246506; PMid:18473941.

27. Russo A, Piovano M, Lombardo L, Garbarino J, Cardile V. Lichen metabolites prevent UV light and nitric oxide-mediated plasmid DNA damage and induce apoptosis in human melanoma cells, Life Sciences 2008;83(13):468-74. https://doi.org/10.1016/j.lfs.2008.07.012; PMid:18721817. 
PICTORIAL ABSTRACT

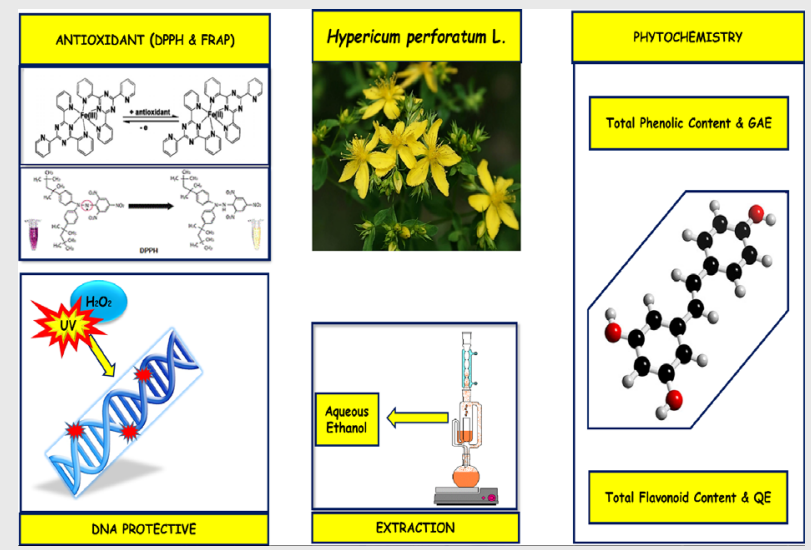

\section{About Authors}
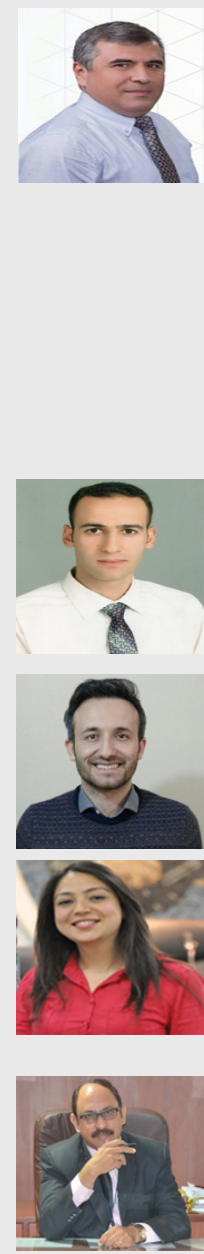
Prof. Dr. Nazim Sekeroglu. University, Department of Molecular Biology.

Prof. Dr. Nazim Sekeroglu: He earned his B.Sc in Agricultural Engineering, Prof. Dr. Sekeroglu earned his PhD degree on Medicinal and Aromatic Plants Cukurova University, Turkey. He is interested in medicinal and aromatic plants since his undergraduate education. He is currently a full-time professor at Kilis 7 Aralık University, Department of Medicinal and Aromatic Plants. He published over 100 peer-reviewed articles and still active on his research area. Additionally, he has organized many international scientific meetings, including congress, symposiums and workshops as chairperson. Furthermore, he is the founder of the Association of medicinal and Aromatic Plants of Mediterranean (AMAPMED), also he is general coordinator of Global Federation of Medicinal and Aromatic Plants (GOFMAP), a worldwide non-profit organization gathering associations related 'Medicinal and Aromatic Plants'. Moreover, he is a member of scientific commissions about Medicinal and Aromatic Plants at Food, Agriculture, Forestry and Health Ministries in Turkey. He has visited more than 50 different countries for scientific purposes.

Mr. Emrah Urlu: He completed his B.Sc in Biology at Kilis 7 Aralık University, Turkey. He then earned his Ms degree from the same university, completed his Ms education under the advisor of

Dr. Muhittin Kulak: He completed his Bachelor's, MSc and PhD in Biology. Since 2009, he has been working at the department of Biology as a research assistant at Kilis 7 Aralık University. He is mainly working on the plant secondary metabolites-induced with abiotic stress factors.

Dr. Sevgi Gezici: After completing her Ms in Molecular Biology and Genetic at Department of Biology, Gaziantep University, Turkey, she earned her Ph.D degree in the Molecular Biology and Genetics form the same University. She has received scholarships for her MSc and Ph.D from TUBITAK, Turkish Scientific Council in Turkey. She is currently science doctor at Gaziantep

Prof. Dr. Raman Dang (M. Pharm, PhD, MBA): General Secretary of APTI, Principal, Krupanidhi College of Pharmacy, Bangalore, is a dynamic, hard-working, enthusiastic professional and responsible person in the field of Pharmaceutical Sciences. He has proven leadership abilities in working as a team, handling multiple tasks, great adaptability to any enterprise's environment. He has more than 60 research papers, 15 review papers, 3 conference proceedings in various peer reviewed national and international journals of repute. Apart from that he has more than 30 general articles contributed in various magazines especially in APTI bulletin. He has contributed 2 book chapters in edited book entitled "Recent progress in Medicinal Plant", Vol- 19, Published by Studium Press, LLC, USA, ISBN: 0-9656038-5-7".

Cite this article: Sekeroglu N, Urlu E, Kulak M, Gezici S, Dang R. Variation in Total Polyphenolic Contents, DNA Protective Potential and Antioxidant Capacity from Aqueous and Ethanol Extracts in Different Plant Parts of Hypericum perforatum L. Indian J of Pharmaceutical Education and Research. 2017;51(2S):S1-S7. 